\title{
PHYTOEXTRACTION AND PHYTOSTABILISATION APPROACHES OF HEAVY METAL REMEDIATION IN ACID MINE DRAINAGE WITH CASE STUDIES: A REVIEW
}

\author{
MANG, K. C. - NTUSHELO, K. ${ }^{*}$ \\ Department of Agriculture and Animal Health, University of South Africa, South Africa \\ (e-mail: kaluchimdimang@yahoo.com; phone: +27-(0)-748-366-063) \\ ${ }^{*}$ Corresponding author \\ e-mail: ntushk@unisa.ac.za; phone: +27-(0)-789-027-944 \\ (Received $5^{\text {th }}$ Aug 2018; accepted $5^{\text {th }}$ Oct 2018)
}

\begin{abstract}
This review discusses phytoextraction and phytostabilisation of acid mine drainage (AMD) alongside with their benefits and limitations with case studies. Furthermore, plants associated with these two approaches of phytoremediation and impact of AMD on aquatic macrophytes used for phytoremediation were also reviewed. Both phytoextraction and phytostabilisation approaches are promising technologies in remediating AMD. However, their limitation of low metal removal and the lack of knowledge of minimum amendments required for their effective remediation call for the proposal, herein made, to combine aquatic macrophytes, as well as include plants from a wide range of families capable of phytoextraction and phytostabilisation in the remediation of AMD.
\end{abstract}

Keywords: aquatic macrophytes, conventional treatment, hyperaccumulators, phytoremediation

\section{Introduction}

The activities of the mine cause the production of acidic water that flows down to nearby water bodies causing long term impairment to biodiversity and waterways. The acidic water produced by the mines is termed acid mine drainage (AMD). Acid mine drainage also known as acid rock drainage is a process that occurs as a result of the contact between oxygenated water and mineral pyrite which leads to the oxidation of the pyrite and the production of acids (Evangelou, 1995; Blowes et al., 2003). Because of its environmental impact, acid mine drainage has attracted great attention all over the world, especially in countries where mining activity is very high. Acid mine water is characterized by low $\mathrm{pH}$ and a very high concentration of sulphates, iron and heavy metals. Many researchers have pointed out that the metal load of the acid mine drainage is of greater concern than the acidity with respect to the environmental damage (Kleinman, 1990; Fyson et al., 1994; Clarke, 1996; Kuyucak, 2002; Filipek et al., 2003). Furthermore, the source of the AMD may remain active for decades or even centuries after the closure of the mine (Modis et al., 1998). Individually mine have unique conditions and ability to produce AMD and therefore interventions should vary from mine to mine. The impact of AMD is dependent on local conditions and varies widely, depending on the geomorphology, the climate and the extent and distribution of the AMD generating deposits. There are no known standard methods for ranking, measuring and reducing the risk of AMD.

Water, air and soil constitute our environment and the process of removing any contaminants or pollutants from the environment is termed environmental remediation. Various technologies which cut across physical, chemical and biological processes have been employed for adequate remediation of polluted water, air and soil. The application of the various technologies depends on the nature of the pollutants. This is also 
applicable to environment polluted with acid mine waters. The conventional technologies which involves the neutralization of the acid in AMD using calcium carbonate, lime, hydrated lime, caustic soda and soda ash often cause the production of voluminous sludge. This sludge represents further environmental problems and an increase in the cost of remediation (Fiset et al., 2003). The high cost of this conventional method of AMD remediation has produced economic pressure and caused more research work to be done by many researchers in order to discover cost-effective and environmentally sound ways to treat AMD.

Phytoremediation is a form of bioremediation studied by many researchers for the treatment of AMD that proved to be cost-effective when compared to the conventional method of treatment (Pilon-Smits, 2005). It applies to all chemical and physical processes that involve plants in degrading or immobilizing contaminants in the environment especially in soil and groundwater. Phytoextraction, phytovolatization, phytostabilzation, rhizodegradation, phytohydraulics, and phytodegradation are the six major types of phytoremediation. Howewer, the focus of this review article is phytoextraction and phytostabilization.

Phytoextraction is also known as phytoaccumulation. Hyperaccumulation of contaminants through the roots of plants and the storage of those contaminants in their stem or leaves tissues is the mechanism of contaminants removal in this phytoremediation method. The contaminants are removed from the environment alongside with the plants when harvested. This phytoremediation method is useful particularly for removing metals from soil. It also provides an avenue of recovering the metals through the incineration of the plants, a process called phytomining. Phytovolatilization involves the taking up of volatile compounds by the plants through their roots. The volatile compounds are transpired directly or converted to metabolites that is capable of being transpired by the plants through their leaves. The contaminants are released to atmosphere.

Phytostabilization is also known as phytosequestration. This method involves the absorption of the contaminants by the roots, and adsorption to the surface of roots. It also involves the production of biochemicals by the plant which are then released into the soil or groundwater around the roots. The biochemicals have the ability to sequester, precipitate, or otherwise, immobilize nearby contaminants. Rhizodegradation occurs in the soil or groundwater that surrounds the plant roots. The exudates from the plants stimulate rhizosphere bacteria surrounding the root of plants to initiate biodegradation of contaminants in the soil. Phytohydraulics also involves the sequestration and degradation of contaminants that come in contact with the deep root of trees. In the work done by Hong et al. (2001), poplar trees were used to contain groundwater plume of methyl-tert-butyl-ether. Phytodegradation applies the mechanism of metabolism or biotransformation of the contaminants as they are taken up into the plant tissues. The transformation of the contaminants can occur in root, stem or leaves of plant depending on the type of plants involved in the phytodegradation.

The Indian Mustard, Brassica juncea (Brassicaceae), a plant familiar to the ones found in Sri Lanka, is found to be the most promising and well-tested plant for phytoextraction. This weedy mustard is successfully cultivated or naturalised in India, Western Egypt, Central Asia and Europe (Prasad and Freitas, 2003). It produces 18 tons of biomass/hectare/crop and it is able to accumulate and translocate high concentrations of $\mathrm{Cr}, \mathrm{Cu}, \mathrm{Cd}, \mathrm{Ni}, \mathrm{Zn}$, and $\mathrm{Pb}$ at the same time to the shoot system (Kumar et al., 1995; Blaylock et al., 1997; Begonia et al., 1998; Zhu et al., 1999). Work done by many 
researchers have shown that this plant has the ability to accumulate heavy metals and the field trial done in the United State of America has shown that this plant can be successfully used in the field remediation of heavy metals and radionuclides (Huang et al., 1998; Lasat et al., 1998; Tucker and Shaw, 2000; Dushenkov, 2003; Qadir et al., 2004). The biomass of Indian Mustard growing in mine soil can be increased by the application of a combination of technosol and biochar and this can improve its effectivity as a bioremediator (Forján et al., 2017). Vetiver grass (Chrysopogon zizanioides) has been successfully grown and used in phytoremediation of gold mine tailings in South Africa (Melato et al., 2016). The good qualities of vetiver grass as a bioremediator are well accepted and a compendious account of this is found in Banerjee et al. (2018). This review examines the use of phytoextraction and phytostabilisation approaches for the treatment of mine tailings alongside with their associated benefits and limitations. Phytoextraction and phytostabilisation of mine tailings in temperate and arid environment were considered alongside with the impact of acid mine drainage on aquatic macrophytes used for phytoremediation.

\section{Impact of Acid Mine Drainage (AMD) on Aquatic Macrophytes: A Case Study of Eichhornia crassipes, Pistia stratiotes and Spirodela polyrhiza}

Activities of the mining industries in the world cause pollution of the surrounding areas. Mining tailings and piles of refuse may contain sulphide minerals such as arsenopyrite. This arsenopyrite is one of the main contamination sources in mining industries. Their exposure to the atmospheric water and oxygen causes their oxidation with the release of potential toxic elements to the environment through AMD system. Sulphur, iron, manganese and arsenic are common elements associated with acid mine drainage and are believe to be highly toxic even at low concentrations (Duker et al., 2005).

Acid mine drainage is believed to influence aquatic systems and alter the biological community structure through the elimination of species in the food chain. In this stance, phytoremediation, an in situ remediation technology, is a low cost option for the reclamation of contaminated environments through the use of plants (Pilon-Smits, 2005). Among all the forms of phytoremediation, phytoextraction and phytostabilisation are the commonly used forms of phytoremediation technology. Macrophytes that freely float in water are mostly used plant species for phytoremediation because of their ability to grow fast, accumulate heavy metals and metalloids in large quantities, survive under harsh conditions and tolerate high concentrations of toxic elements (Mishra et al., 2008a; 2008b).

The major setback of phytoremediation studies is that they are limited to some selected plant species and few metals (Hassan et al., 2007; Rahman et al., 2007). As a result, there is an information paucity on the simultaneous absorption of several contaminants especially, in acid mine drainage. Eichhornia crassipes, Pistia stratiotes and Spirodela polyrhiza species possess the ability to absorb several different elements to some extent and simultaneously accumulate heavy metals and toxic metalloids from acid mine drainage. Preliminary work done by Michelle et al. (2010) showed that Pistia stratiotes and Spirodela polyrhiza were susceptible to low $\mathrm{pH}$ in the aquatic medium which is the main characteristic of acid mine drainage. Furthermore, they observed that E. crassipes was more tolerant to acidic environment (Figure 1). The decrease in the chlorophyl a content was also observed to be another effect of acid mine 
drainage on plants as seen in $P$. stratiotes and $S$. polyrhiza, due to the necrosis on the leaves.

Eichhornia crassipes plants were also observed to accumulate part of the soluble arsenic from acid mine drainage in their different tissues with the root accumulating more of the heavy metals. Furthermore, the work done by Mokhtar et al. (2011) indicated that $E$. crassipes showed $97.3 \%$ efficiency for copper removal in an aqueous solution containing various concentrations of copper. Pistia stratiotes and S. polyrhiza die when exposed to acid mine drainage. The work done by Michelle et al. (2010) gave an insight on the ability of some aquatic macrophytes to accumulate heavy metals. However, there exists the need to further evaluate the simultaneous absorption of other heavy metals by aquatic macrophytes and their interactions to enhance the development of a better phytoremediation technology for acid mine drainage while preserving the aquatic macrophytes capable of accumulating the heavy metals.

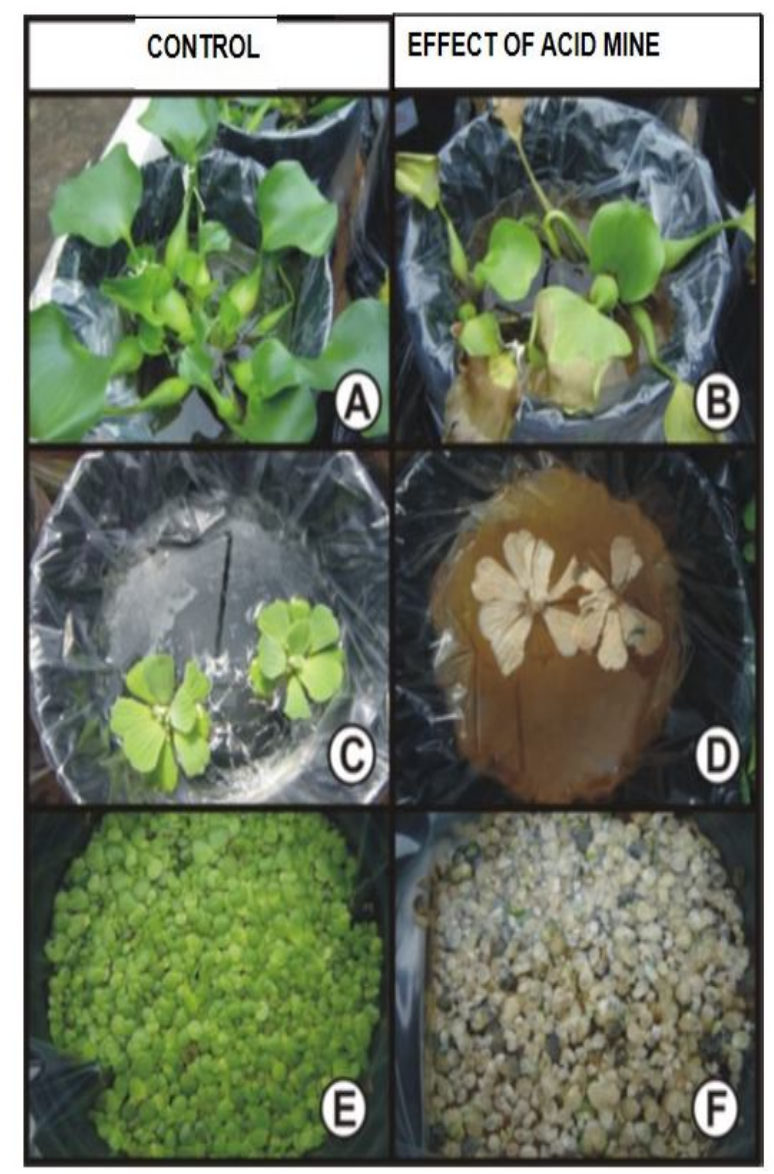

Figure 1. Phytotoxic effects of acid mine drainage in aquatic floating macrophytes. (A-B, $E$. crassipes; $C$-D, P. stratiotes; E-F, S. polyrhiza) Source: Michelle et al., 2010

\section{Limitations of Phytoremediation Using Aquatic Plants}

Various research endeavours have shown phytoremediation to be a better environmentally friendly and cost-effective method for the treatment of wastewater and polluted environments with respect to conventional methods (Sood et al., 2012; Sharma et al., 2014; Newete and Byrne, 2016). The production of biomass through its fast 
growth ability gave more advantages to this method of remediation however, its inability to tolerate high concentrations of metal and the influence of seasons on its effectiveness is disadvantageous (Rai, 2008; Mannino et al., 2008).

Sharma et al. (2014) stated that phytoremediation is used either as a secondary or a tertiary treatment method for industrial or mine wastewater treatment because of high concentration of heavy metals and the toxicity of the metals. As a result of this, Rai (2008) encouraged regular harvest and safe disposal of the biomass for effective phytoremediation treatment in order to avoid the release of the absorbed or adsorbed metals back into their source when the plant dies and decompose.

\section{Plants Associated with Phytoextraction and Phytostabilisation of Heavy Metals: A case study of Sri Lanka and South Africa}

The success of phytoextraction and phytostabilisation is dependent on the plant species available. Baker and Whiting (2002) also indicated that those plants that can carry out these two phytoremediation approaches in remedying acid mine drainage are those native to the region of interest and are able to tolerate and accumulate high concentrations of heavy metals. Baker et al. (2000) further pointed out that many hyperaccumulators of heavy metals such as $\mathrm{Cu}, \mathrm{Co}, \mathrm{As}, \mathrm{Zn}, \mathrm{Pb}, \mathrm{Mn}, \mathrm{Se}, \mathrm{Cd}$, and $\mathrm{Ni}$ are characterised by their ability to survive high concentrations of these heavy metals and always endemic to metal-rich substrates. Over 420 species of heavy metals hyperaccumulators that belong to about 45 plant families have been identified (Cobbett, 2003). In addition, Krämer (2003) reported that new hyperaccumulators are being discovered from field collections with only few number of them tested in the laboratory for their behaviour and mechanisms of hyperaccumulation. Several fascinating patterns have been observed since the events of hyperaccumulators discovery (Ernst, 2000; Baker and Whiting, 2002). First, many families of plants such as Asteraceae, Brassicaceae, Euphorbiaceae, Fabaceae, Flacourtiaceae, and Violaceae were found to contain large numbers of hyperaccumulators. This implied that several genera within the families may be predisposed or preadapted to tolerate high level of heavy metals. The second pattern observed was the high percentage of these hyperaccumulators in tropical regions of the world. About 320 species of Ni hyperaccumulators discovered, two-thirds were found in the tropical regions of the world (Reeves, 2003; Proctor, 2003). The third pattern indicated that more than $80 \%$ of the identified hyperaccumulators take up more $\mathrm{Ni}$ than the other metals. The reasons behind this observed pattern of hyperaccumulators occurrence could be attributed to the combination of the following factors:

- Availability of time for the evolution of these species of hyperaccumulators in the tropical regions.

- High weathering of naturally occurring ore-bodies in tropical regions which imposes a greater selective pressures on indigenous floras.

- Provision of a selective advantage in dealing with other stresses of tropical regions due to the heavy metal accumulation traits in the hyperaccumulators.

- The availability of $\mathrm{Ni}$ over the other metals due to the presence of many tracts of Ni-enriched serpentine outcrops along continental margins.

- The interest of researchers in discovering hyperaccumulators in tropical regions.

Reeves (2003) reported that over 50 species of Ni hyperaccumulators have been found endemic to the metal-rich serpentine outcrops of New Caledonia (an island). These include species from genera such as Cledion (Euphorbiaceae), Argophyllum 
(Grossulariaceae), Casearia (Flacourtiaceae), Geissois (Cunoniaceae), Homalium (Flacourtiaceae), Hybanthus (Violaceae), Oncotheca (Oncothecaceae), Pancheria (Cunoniaceae), Phyllanthus (Euphorbiaceae), and Xylosma (Flacourtiaceae) (Jaffré et al., 1979; Reeves, 2003). Jaffré et al. (1976) found that the latex of a small tree called Seberita acuminata (Sapotaceae) that is endemic in the island contains more than $20 \%$ $\mathrm{Ni}$ by dry weight. Proctor (2003) reported that the Asian region have few identified hyperaccumulator and most of them are closely related to the ones found in Sri Lanka. Myristica (Myristicaceae), Planchonella (Sapotaceae), and Trichospermum (Tiliaceae) are the genera of $\mathrm{Ni}$ hyperaccumulator found in Indonesia. Another Asian genus called Rinorea (Violaceae) has two Ni hyperaccumulating species (Brooks and Wither, 1977a,b; Wither and Brooks, 1977). Wither and Brooks (1977) identified that Rinorea benghalensis collected from Sri Lanka's herbarium has $1 \% \mathrm{Ni}$ hyperaccumulation by dry weight. Rajakaruna and Baker (2004) was in the opinion that this species may have been collected from the serpentinized areas of Katupotha in the south-central part of island. The same species was also found in Sabah (Jopony and Tongkul, 1999) and found to hyperaccumulate Ni. The genera such as Brackenridgea (Ochnaceae), Dichapetalum (Dichapetalaceae), Walsura (Meliaceae) as well as Phyllanthus (Euphorbiaceae) and Shorea (Dipterocarpaceae) widely represented in the Sri Lankan flora were found to hyperaccumlate Ni in Sabah and Phillipines (Proctor et al., 1989; Baker et al., 1992). Jayasekera and Rossbach (1994, 1996) suggested that there may be several taxa in Sri Lanka with the capacity to accumulate high concentrations of heavy metals.

Sri Lankan endemic plants such as Crotalaria biflora (Fabaceae), Evolvulus alsinoides (Convolvulaceae), Hybanthus enneaspermus (Violaceae) showed high level of whole-plant $\mathrm{Ni}$ hyperaccumulation; and Clerodendrum infortunatum (Verbenaceae), Croton bonplandianus (Euphorbiaceae), Geniosporum tenuiflorum (Lamiaceae), Tephrosia villosa (Fabaceae), and Waltheria indica (Sterculiaceae) showed high level of whole-plant $\mathrm{Cu}$ hyperaccumulation (Rajakaruna and Bohm, 2002). It is worth noting that $\mathrm{Cu}$ hyperaccumulation is a rare and the taxa shown to accumulate $\mathrm{Cu}$ need further review to confirm these preliminary findings. Cassia kleinii (Fabaceae), a woody shrub well-suited, found in $\mathrm{Ni}$ - and $\mathrm{Cr}$-enriched serpentine outcrop of Ussangoda, has shown Ni hyperaccumulation (Rajakaruna and Bohm, 2002; Iqbal et al., 2006).

Combretum erythrophyllum (River Bush-willow), an indigenous South African tree species that may reach a height of approximately $5 \mathrm{~m}$ within 5 years and can further grow to a height of about $15 \mathrm{~m}$ after 50 years (Stoffberg et al., 2008), has been used as a phytoextraction and phytostabilisation option on several tailings dams in Johannesburg. This tree can survive in high salinity areas and bears seed. McGaw et al. (2001) reported that the leaves and back of this tree is used in traditional medicine around southern Africa. Based on this, care needs to be taken in the harvest of this tree for traditional medicine when used for phytoremediation.

Eucalyptus camaldulensis (Red River gum) is an invasive plant with Australia as its native country. It is also found in South Africa. This tree is able to strive well in a high salt and acidic conditions and other harsh conditions including drought. It is a hyperaccumulator of $\mathrm{Mn}$ and $\mathrm{Pb}$. Singh et al. (2010) found out that E. camaldulensis showed high productivity and great reduction in most soil mineral concentrations in an experiment done to assess mineral uptake of Acacia nilotica L. (babool), Dalbergia sissoo L. (sissoo) and Eucalyptus camaldulensis seedlings. From the findings 
of this work, it was indicated that E. camaldulensis was the best option for the rehabilitation of soil because it can tolerate high salt concentration in the soil and water. It is important that sterile plants are planted for phytoextraction to minimise the risk of invasion of the surrounding environment.

Tamarix usneoides (Wild Tamarix) is native to South Africa and can thrive well in highly saline environments. The plant possesses a good root system that can penetrate deep water tables in arid environments and an adaptive salt glands that can secret excess salts. In South Africa, this plant is used for phytoremediation with success around tailings dams. Sporobolus spicatus (Salt Grass) is adapted to growing salt pan edges, marsh and river edges as perennial grass. The salt accumulation by the shoots of this grass increases with increasing soil salinity (Ramadan, 2001). This plant is recommended to be used for phytoremediation because of its ability to survive in adverse and wet conditions.

\section{Phytoextraction of Metals in Mine Tailings: A Case Study of Temperate and Arid Environments}

Phytoextraction of metals especially from mine tailings entails the application of metal-hyperaccumulating plants that accumulate the metals either in their root, leaves or stem. This accumulation of heavy metals is followed by the harvesting of the plants. The harvested plants could either be destroyed or the accumulated heavy metals are recycled and reused. Plants that concentrate metals into above-ground biomass at a very high concentrations are known as hyperaccumulators. These hyperaccumulators have the tendency to accumulate metals at levels of $0.01-1 \%$ of the plant biomass produced. This is dependent on the specific metal being absorbed by these plants (Brooks, 1998; Baker et al., 2000). High biomass production and fast growth rates are the key characteristics of these hyperaccumulators that enhances maximum accumulation of metals. Accumulation factor which is the ratio of metals in the shoot tissue to the metal in the contaminated environment, and translocation factor which is defined as the ratio of the metals in the shoot to the metals in the root of the plants are other measures used to identify and define hyperaccumulators. Based on accumulation factors, translocation factors, high biomass and fast growing rate, over four hundred species of hyperaccumulators that belong to 45 families have been identified as effective hyperaccumulators of metals from contaminated soils with species specifically capable of phytoextraction in mine tailings being identified (Baker et al., 2000; Deng et al., 2007; Turnau et al., 2007). The general method of identifying and defining hyperaccumulators is the metal concentration in the shoot tissues of plants. Furthermore, accumulation factor is also necessary for identifying the feasibility of phytoextraction. This feasibility of phytoextraction means the number of cropping cycles required for the metal removals to the level that is accepted (Zhao et al., 2003).

For the identification of potential plants candidates for phytoextraction in acid mine drainage, several surveys of plants colonizing mine tailings together with hyperaccumulators grown in mine tailings have been done. However, phytoextraction of metals from mine tailings are faced with major challenges. Phytoextraction of metals in mine tailings is known to be generally poor because of low metal bioavailability in tailings amended with compost to enhance the growth of plants (Knight et al., 1997; Meerts and Van Isacker, 1997; Salt et al., 1997; Bennett et al., 2003). Furthermore, Krzaklewski and Pietrzykowski (2002) observed that some plant species have the ability 
to survive and colonize mine tailings but their metal accumulation was not sufficient for them to be used as hyperaccumulators. In order to enhance hyperaccumulation of metals by hyperacumulators, metal chelators have been tested and used to enhance hyperaccumulation. However, their use posed a problem of phytotoxicity for the plants. Based on this, chelators are applied generally after good plant biomass production is achieved (Berti and Cunningham, 2000). Another challenge faced when chelators are applied is the leaching of metals into the groundwater especially in temperate environments due to increase solubility of metals in the mine tailings (Wu et al., 1999; Schmidt, 2003). This leaching of metals into groundwater leads to their pollution.

Transgenic hyperaccumulator plants have been researched and explored for remediation of mine tailings in many countries of the world. However, the major drawback of these transgenic hyperaccumulators is their adverse impacts on species diversity, soil ecosystems, and the food chain (Wolfenbarger and Phifer, 2000; Wolfe and Bjornstad, 2002). Furthermore, their invasive potentials and ability to colonize disturbed areas in desert environments and establishment of late successional species is also a major concern in the use of transgenic hyperaccumulators (Castellanos et al., 2005). In order to enhance the proper management of this transgenic hyperaccumulators, the use of sterile clones, harvesting of plants before flowering, selection of species that will not outcompete indigenous plants have been encouraged (Pilon-Smits and Pilon, 2002; Snow et al., 2005). Wolfe and Bjornstad (2002) finally observed that poor public acceptance may pose a problem in the implementation of transgenic hyperaccumulators.

Plants growing in temperate environments where there are mine tailings experience low $\mathrm{pH}$, metal toxicity, lack of soil structure, and low nutrient content as challenges that oppose their developments. Those plants that are able to tolerate and overcome the challenges in temperate environments often face the problems of low biomass production. This low biomass production impedes the success of phytoextraction in the temperate environments as the success of metal accumulation by the plants depend on the biomass production. A typical example is found in Europe where the populations of Thlaspi caerulescens were found to be thriving in metal contaminated sites and mine tailing sites with the ability to accumulate the metals. In the United Kingdom, T. caerulescens were found to thrive in mine tailings and mine spoils. The plant was found to accumulate $50-160 \mathrm{mg} \mathrm{kg}^{-1} \mathrm{Cd}$ and $13,000-19,000 \mathrm{mg} \mathrm{kg} \mathrm{Kn}^{-1} \mathrm{Zn}$ with accumulation factors of $\mathrm{Zn}>1$ (Baker et al., 1994). The accumulation factors of the plant was observed to increase up to 73 and 40 for $\mathrm{Cd}$ and $\mathrm{Zn}$ respectively when the plant was exposed to a lower level of Cd to Zn ratio (Zhao et al., 2003).

Study done in greenhouse using $T$. caerulescens exposed to a mine spoil containing up to $3300 \mathrm{mg} \mathrm{kg}^{-1} \mathrm{Zn}$ and $58 \mathrm{mg} \mathrm{kg}^{-1} \mathrm{Cd}$ to evaluate its phytoextraction potential showed that the plant accumulated $250 \mathrm{mg} \mathrm{Cd} \mathrm{kg} \mathrm{plant} \mathrm{biomass}^{-1}$ and $8,000 \mathrm{mg} \mathrm{Zn} \mathrm{kg}^{-1}$ plant biomass ${ }^{-1}$ (Knight et al., 1997). As a result of low biomass production of the plant in mine tailings, an approximate 100 - 1200 cropping cycles would be needed to remove $\mathrm{Cd}$ and $200-600$ cropping cycles to remove $\mathrm{Zn}$ from the studied mine tailings. These cropping cycles translated into decades for complete remediation of the mine tailings. The obtained results showed that $T$. caerulescens may be useful for the remediation of environment contaminated with low $\mathrm{Cd}$ and $\mathrm{Zn}$ and may not be suitable for more highly contaminated mine spoil that was studied.

In the quest to improve phytoextraction efficiency in mine tailings, two transgenic strains of Brassica juncea (L.) Czern were discovered and observed to accumulate up to 
1.5 to 3 -fold more metal $(\mathrm{Cd}, \mathrm{Cr}, \mathrm{Cu}, \mathrm{Pb}, \mathrm{Zn})$ than the wild type strain in a greenhouse study (Bennett et al., 2003). The enzymes cglutamylcysteine synthetase (ECS) and glutathione synthetase (GS) that affect production of the metal-binding thiol peptides, phytochelatin and glutathione, respectively were overproduced by the transgenic strains. Twenty five per cent and five per cent of $\mathrm{Cd}$ and $\mathrm{Zn}$ respectively were reduced by the strains of this transgenic $B$. juncea from compost-amended tailings however, leaching was later discovered as the primary reason for metal reduction in this study (Ernst, 2005). Bennett et al. (2003) indicated that the addition of compost and lime required for growth of $B$. juncea in the mine tailings decreased plant metal bioavailability and hence the overall phytoextraction efficiency of the transgenic plants.

The growth of plants in arid environment is also faced with the challenges of lack of water and often saline conditions in addition to low $\mathrm{pH}$, metal toxicity, low nutrients and lack of soil structure. Despite the challenges faced by the plants in this environment, a promising list of natural hyperaccumulators that have the ability to colonize mine tailings have been identified however, few of them have been studied in the greenhouse to evaluate their hyperaccumulation potentials (Leita et al., 1989; Bech et al., 2002; Gonzalez and Gonzalez-Chavez, 2006). In Spain, Cichorium intybus L. and Cynodon dactylon (L.) Pers. which naturally colonize the mine tailings were evaluated for lead $(\mathrm{Pb})$ accumulation. This study was carried out on artificially $\mathrm{Pb}$ contaminated potting soils. The shoot $\mathrm{Pb}$ accumulation was observed to be $800-1500$ and $400-$ $1200 \mathrm{mg} \mathrm{kg}^{-1} \mathrm{~Pb}$ for $C$. intybus and $C$. dactylon, respectively. Furthermore, it was observed that shoot accumulation of the metal had no inhibition effect on the plant growth and biomass production. However, the limitation of this study was that the authors were not able to show how this phytoextraction ability of these plants would translate to a mine tailings environment (Del Rio-Celestino et al., 2006).

Conesa et al. (2007b) carried out a field and greenhouse study on Lygeum spartum L. a grass known to colonize mine tailings site in Mediterranean regions, to evaluate the phytoextraction ability of the grass. It was observed in the field and greenhouse that the metal accumulation was low with the exception of zinc which was extremely high and between 3000 to $6000 \mathrm{mg} \mathrm{kg}^{-1}$ when plants were irrigated and fertilized in the greenhouse. Frérot et al. (2006) observed in their work that contrary to the believe that Armeria arenaria (Pers.) Schult., Festuca arvernensis Auquier, and Koeleria vallesiana (Honck.) Gaudin are non-hyperaccumulators, they were found to hyperaccumulate $\mathrm{Pb}$ at $1,000-2,000 \mathrm{mg} \mathrm{kg}^{-1}$ in the field.

Elevated salinity is the most common characteristics of mine tailings in arid environments. The electrical conductivity of the environment is believed to influence by the salinity and this electrical conductivity was observed in arid environments with high salinity $\left(22 \mathrm{dS} \mathrm{m}^{-1}\right)$ to be greater than the tolerant level for plants (Munshower, 1994; Marschner, 1995). Atriplex spp accumulate sodium and potassium at a high concentrations in mine tailings and uncontaminated soils and as a result, they are referred to as halophytes (Osmond et al., 1980; Mendez et al., 2007). The work done by Lutts et al. (2004) in a hydroponic greenhouse study using Atriplex halimus L. showed that the plant can take up 830 and $440 \mathrm{mg} \mathrm{kg}$ plant tissue ${ }^{-1}$ of Cd and $\mathrm{Zn}$ respectively in shoot biomass and did not display symptoms of toxicity during growth. This high concentration of the accumulated metals may have been influenced by the low concentrations of cations $\left(\mathrm{Na}^{+} / \mathrm{K}^{+}\right)$in the hydroponic growth medium. However, the occurrence of the same result in the field study is not known. 


\section{Limitations of Phytoextraction}

The widespread use of phytoextraction as a remediation strategy for mine tailings is faced with major drawbacks. The time taken for a complete phytoextraction might be so long especially with a highly metal polluted mine tailings. Plant metal bioavailability and metal extraction efficiency may decrease as a result of the distribution of different metals in mine tailings alongside with compost amendments required for the plant growth. Ernst (2005) indicated the polymetallic nature of mine tailings as another drawback to the success of the spread of phyotextraction as hyperaccumulators can only accumulate one or two metals and as a result, multiple plant species and ecotypes are required. This drawback is further strengthened in arid regions with high saline content of mine tailings and the preference of $\mathrm{Na}^{+} / \mathrm{K}^{+}$by many halophytes (Osmond et al., 1980; Munshower, 1994; Marschner, 1995). Characteristics of plants can also decrease the efficiency of plants to metals from mine tailings. Keller et al. (2003) pointed out that hyperaccumulators generally possess shallow root zone which limit metal removal by plant rooting depth. Metal extraction efficiency may be reduced in tailings with high metal concentrations. Generally, the harsh conditions of mine tailings influences biomass production of plants and consequently, the efficiency of phytoextraction (Ernst, 2005; Audet and Charest, 2007).

Wildlife is in danger of metal exposure as a result of the accumulation of the metals in the shoot system of the hyperaccumulators eatable by wildlife animals. Wood et al. (1995) pointed out that the worst scenario can be seen in arid regions where food sources are limited. All these drawbacks are believed to influence the cost of implementing phytoextraction by making it high and optimisation of this process may also require expensive inputs. Furthermore, the cost of harvesting, disposing and reseeding of hyperaccumulators which may be required for many cropping cycles add to the total cost of the technology (Cunningham and Berti, 2000). In conclusion, there is the need to consider the safety of wildlife. This do not remove the remediation application of phytoextraction in mine tailings. However, there is the need to balance the costs associated with this strategy and the potential value of the land once it is reclaimed.

\section{Phytostabilization of Mine Tailings: A Case Study of Temperate and Arid Environments}

Phytostabilization of mine tailings involves the establishment of plants that have extensive root system which will enable them to create steady vegetative cap that does not accumulate metals into above-ground tissues. The mechanism of action of established plants in the mine tailings include sorption of metals onto the root surfaces, accumulation of metals in the root tissue and stabilization of metals through precipitation (Cunningham et al., 1995; Wong, 2003). Furthermore, established plants in the mine tailings for phytostabilization should have the ability to enhance diverse heterotrophic microbial community interaction that will encourage the growth of plants and promote the transformation of the materials in the mine tailings necessary for the improvement of the soil structure (Mummey et al., 2002a; Glick, 2003; Wong, 2003; Mendez et al., 2007). The established plants also provide the initial plant cover that enhances the growth and establishment of other plants in the environment leaving the environment with diversified and self-sustaining vegetative cap that reduces water erosion, leaching processes and eolian. 
The plants used for phytostabilization varies from region to region and depends on the nature of metal contaminants in the mine tailings. Furthermore, physicochemical factors influences the stability and diversity of naturally established plant communities in the same regions (Conesa et al., 2007a). As a result, physicochemical characteristics of individual mine tailings sites need to be considered before the establishment of plants required for phytostabilization. There is also the need to amend the mine tailings with compost manure or lime required for the growth of the plants so as to remove any toxic effect and decrease metal bioavailability. The plants selected for phytostabilization need not to translocate metals to shoot tissues. This is to safe guard the life of wildlife animals that may depend on them for survival and also to prevent surface contamination. In view of this, the ratio of shoot metal concentrations to root metal concentration or soil metal concentration should be less than one. The plants should also meet the US Domestic Animal Metal Toxicity Limits to prevent exposure to foraging animals (Wood et al., 1995; NRC, 2005).

Grasses are mostly used for phytostabilization in temperate environments because of their rapid growth and extensive rooting systems. In Europe, Festuca spp. and Agrostis spp. are native grass species that are mostly used for phytostabilization. They are also used in the US and China for phytostabilization (Smith and Bradshaw, 1979; Ye et al., 1999; Pierzynski et al., 2002; Von Willert and Stehouwer, 2003). A greenhouse experiment done in Scotland by Pichtel and Salt (1998) showed that application of NPK fertilizer only enhances the growth of Festuca ovina L. and F. rubra in a moderately acidic $\mathrm{Pb} / \mathrm{Zn}$ mine waste sample.

Several field trials done in the UK indicated successful establishment of $F$. rubra and Agrostis tenuis Sibthorp in $\mathrm{Pb} / \mathrm{Zn}$ and $\mathrm{Cu}$ mine tailings with a combination of fertilizers and lime (Smith and Bradshaw, 1979). Furthermore, native plants have been explored by many studies in combination of soil cover to achieve phytostabilization. This was seen in the work done in Washington, US by Kramer et al. (2000) using Alnus viridis subsp. sinuate (Regel) and Anaphalis margaritacea (L.) where they observed the two plants demonstrating adequate plant biomass and shoot tissue exclusion of high concentrations of $\mathrm{Al}$ and $\mathrm{Zn}$ when grown in copper mine tailings amended with biosolids-woodchip mixture before the planting of the plants. Similarly, in China, Shu et al. (2001) carried out a study using 41 native seed species from a soil seed bank obtained from nearby uncontaminated areas. They established the plants in a $\mathrm{Pb} / \mathrm{Zn}$ mine tailings following application of an 8-cm top-soil layer over the tailings material and observed that 9 of the plants survived with three of them showing both good plant coverage and low metal accumulation.

Drought-, salt- and metal-tolerant plants are required for effective phytostabilization of mine tailings in arid and semiarid climates. Addition of an organic amendment and irrigation enhance the success of re-vegetation in arid environment. In semiarid Western Australia Atriplex spp. are known pioneer plants on mine tailings (Osmond et al., 1980; Jefferson, 2004). An irrigated greenhouse study conducted by Mendez et al. (2007), showed that a minimum of $10 \%$ compost addition was required for adequate growth of Atriplex lentiformis (Torr.) in both moderately acidic and extremely acidic $\mathrm{Pb} / \mathrm{Zn}$ mine tailings. They also observed that shoot uptake of metals did not exceed US Domestic Animal Metal Toxicity Limits.

Sabey et al. (1990) also conducted a greenhouse study using biosolids which indicated that a sludge application of $60 \mathrm{Mg} \mathrm{ha}^{-1}$ was required for growth of Atriplex canescens (Pursh) in copper mine tailings. One disadvantage of the high sludge 
application observed by them was elevated $\mathrm{Cu}$ concentrations tissues of the leaves that exceeded recommended US Domestic Animal Metal Toxicity Limits by 5-fold. Rosario et al. (2007) conducted a field experiment to examine the impact of compost on establishment of $A$. canescens in an alkaline mine tailing site in southern Arizona, US. Forty four litres of water over the first eight months of growth was administered to the individual plants. Similar plant growth results were obtained in both composted and uncomposted tailings and $80 \%$ of transplants survived. Further observation in this study was that $\mathrm{Pb}$ exceeded the US Domestic Animal Metal Toxicity Limits in some plants by up to 3-fold. The information obtained from these studies implied that plant growth requirements and physicochemical factors of the mine tailings determines the amount and type of amendment required by the plants. Therefore, amendment requirements are both site- and plant species-specific.

Re-vegetation through the use of direct-seeding in field studies that have been performed in an arid environment was promising. Study performed in Zimbabwe by Piha et al. (1995) using direct seeding method with no irrigation in a tin mine tailings site where the seeds were subjected initially to seven weeks of drought produced $40 \%$ plant cover with a mixture of grasses and legumes after the first growing season using only an initial addition of NPK fertilizer. The study done in South Africa by Van Rensburg and Morgenthal (2004) in a platinum tailings with seeds from a mixture of grasses and amended with fertilizer produced average plant cover of $2 \%$. However, the authors suggested that lack of irrigation and poor timing that did not take advantage of the seasonal rainfall are the cause of these poor results. The seeding study done by Windsor and Clements (2001) in a gold mine tailing site in where the seeds were irrigated showed that seedling density was 3-fold greater in irrigated plots compared to plots without irrigation. This implied that in arid and semi-arid environments, irrigation significantly increases the plant establishment. If irrigation is not feasible, direct seeding studies require precise timing to take advantage of the normal rainfall season.

\section{Limitations of Phytostabilization of Mine Tailings}

Phytostabilization being a long-term field studies makes it difficult to evaluate the overall success of this strategy. A 20-year study carried out by Mummey et al. (2002b) showed that both plant and microbial diversity in a re-vegetated mining site was low compared to an adjacent undisturbed site in a semiarid grassland. However, plant cover gave a promising result of the use of this technology because it was higher than the ones found in the undisturbed site. Complete plant coverage is dependent on the environment. Semi-arid and arid shrublands are not likely to produce a complete plant coverage when compared to the temperate environments. This becomes a limitation to the success of the use of phytostabilization to remedy acid mine tailings. The difference in plant coverage in arid and temperate environment is dependent on nitrogen availability, water use efficiency and light. Availability of nitrogen and efficiency of water use influences plant dynamics in semi-arid and arid environment whereas light and nitrogen availability influences plant dynamics in temperate environment (Tilman, 1988; Gebauer and Ehleringer, 2000). Therefore, infrequent rainfall could result to increase mortality of the secondary successional plant communities in semi-arid and arid environment (Watson et al., 1997; Castellanos et al., 2005). To overcome some of the limitations it is recommended that a comprehensive approach which employs various strategies can be embarked upon. Emenike et al. (2018) explores the combined 
use of plants and microbes to biotransform contaminated soils and similar mechanisms including the addition of nutrients and nanoremediation as suggested by Das (2018) may prove sustainable. The table below gives a summary of plants and their bioremediation potentials (Table 1).

Table 1. Summary of plant species used in phytoextraction and phytostabilization of metals in acid mine drainage

\begin{tabular}{|c|c|c|c|c|}
\hline Plant species & Family & $\begin{array}{c}\text { Remediation } \\
\text { Mechanism }\end{array}$ & Achieved Results & References \\
\hline Chrysopogon zizanioides & Poaceae & Phytoextraction & $\mathrm{Zn}, \mathrm{Cu}$, and $\mathrm{Ni}$ removal & Melato et al. (2016) \\
\hline Brassica juncea & Brassicaceae & Phytoextraction & $\begin{array}{l}\mathrm{Cr}, \mathrm{Cu}, \mathrm{Cd}, \mathrm{Ni}, \mathrm{Zn} \text {, and } \mathrm{Pb} \\
\text { accumulation and removal }\end{array}$ & $\begin{array}{c}\text { Kumar et al. (1995); } \\
\text { Blaylock et al. } \\
\text { (1997); Begonia et } \\
\text { al. (1998); Zhu et al. } \\
\text { (1999) }\end{array}$ \\
\hline Eichhornia crassipes & Pontederiaceae & Phytoextraction & $\begin{array}{l}97.3 \% \mathrm{Cu} \text { removal } \\
\text { efficiency in aqueous } \\
\text { solution, arsenic } \\
\text { hyperaccumulation }\end{array}$ & $\begin{array}{l}\text { Mokhtar et al. } \\
\text { (2011); Michelle et } \\
\text { al. (2010) }\end{array}$ \\
\hline Waltheria indica & Malvaceae & Phytoextraction & $\begin{array}{l}\text { High level of whole-plant } \\
\mathrm{Cu} \text { removal }\end{array}$ & $\begin{array}{l}\text { Rajakaruna and } \\
\text { Bohm (2002) }\end{array}$ \\
\hline Cassia kleinii & Fabaceae & Phytoextraction & Ni removal & $\begin{array}{l}\text { Iqbal et al. (2006); } \\
\text { Rajakaruna and } \\
\text { Bohm (2002) }\end{array}$ \\
\hline Thlaspi caerulescens & Brassicaceae & Phyotextraction & $\begin{array}{c}\text { Accumulation of } 50-160 \\
\mathrm{mg} \mathrm{kg}^{-1} \mathrm{Cd} \text { and } 13,000- \\
19,000 \mathrm{mg} \mathrm{kg}^{-1} \mathrm{Zn} \\
\end{array}$ & $\begin{array}{l}\text { Baker et al. (1994); } \\
\text { Zhao et al. (2003) }\end{array}$ \\
\hline Seberita acuminata & Sapotaceae & Phytoextraction & Removal of over $20 \%$ of $\mathrm{Ni}$ & Jaffré et al. (1976) \\
\hline Rinorea benghalensis & Violaceae & Phytoextraction & $1 \%$ removal of $\mathrm{Ni}$ & $\begin{array}{c}\text { Wither and Brooks } \\
\text { (1977) }\end{array}$ \\
\hline Cichorium intybus $\mathrm{L}$. & Asteraceae & Phytoextraction & $\begin{array}{c}\text { Removal of } 800-1500 \mathrm{mg} \\
\mathrm{kg}^{-1} \mathrm{~Pb} \text { through shoot } \\
\text { accumulation }\end{array}$ & $\begin{array}{c}\text { Del Rio-Celestino et } \\
\text { al. (2006) }\end{array}$ \\
\hline $\begin{array}{c}\text { Cynodon dactylon (L.) } \\
\text { Pers. }\end{array}$ & Poaceae & Phytoextraction & $\begin{array}{c}\text { Removal of } 400-1200 \mathrm{mg} \\
\mathrm{kg}^{-1} \mathrm{~Pb} \text { through shoot } \\
\text { accumulation }\end{array}$ & $\begin{array}{l}\text { Del Rio-Celestino et } \\
\text { al. (2006) }\end{array}$ \\
\hline $\begin{array}{c}\text { Armeria arenaria (Pers.) } \\
\text { Schult., Festuca } \\
\text { arvernensis Auquier, and } \\
\text { Koeleria vallesiana } \\
\text { (Honck.) } \\
\end{array}$ & $\begin{array}{c}\text { Plumbaginaceae, } \\
\text { Poaceae, and Poaceae } \\
\text { respectively }\end{array}$ & Phytoextraction & $\begin{array}{l}\text { Removal of } 1,000-2,000 \\
\qquad \mathrm{mg} \mathrm{kg}^{-1} \mathrm{~Pb}\end{array}$ & Frérot et al. (2006) \\
\hline $\begin{array}{l}\text { Crotalaria biflora, } \\
\text { Evolvulus alsinoides, } \\
\text { and Hybanthus } \\
\text { enneaspermus }\end{array}$ & $\begin{array}{c}\text { Fabaceae, } \\
\text { Convolvulaceae, and } \\
\text { Violaceae respectively }\end{array}$ & Phytoextraction & $\begin{array}{l}\text { Whole-plant } \\
\text { hyperaccumulation of } \mathrm{Ni}\end{array}$ & $\begin{array}{l}\text { Rajakaruna and } \\
\text { Bohm, (2002) }\end{array}$ \\
\hline $\begin{array}{c}\text { Clerodendrum } \\
\text { infortunatum, Croton } \\
\text { bonplandianus, } \\
\text { Geniosporum } \\
\text { tenuiflorum, Tephrosia } \\
\text { villosa, and Waltheria } \\
\text { indica }\end{array}$ & $\begin{array}{c}\text { Verbenaceae, } \\
\text { Euphorbiaceae, } \\
\text { Lamiaceae, Fabaceae, } \\
\text { and Sterculiaceae } \\
\text { respectively }\end{array}$ & Phytoextraction & $\begin{array}{c}\text { Whole-plant } \\
\text { hyperaccumulation of } \mathrm{Cu}\end{array}$ & $\begin{array}{l}\text { Rajakaruna and } \\
\text { Bohm, (2002) }\end{array}$ \\
\hline Atriplex halimus L. & Amaranthaceae & Phytoextraction & $\begin{array}{c}\text { Accumulation of } 830 \text { and } \\
440 \mathrm{mg} \mathrm{kg} \text { plant tissue }{ }^{-1} \text { of } \\
\mathrm{Cd} \text { and } \mathrm{Zn} \text { respectively in } \\
\text { shoot biomass }\end{array}$ & Lutts et al. (2004) \\
\hline Lygeum spartum $\mathrm{L}$. & Poaceae & Phytoextraction & $\begin{array}{c}\text { Removal of } 3000-6000 \mathrm{mg} \\
\mathrm{kg}^{-1} \mathrm{Zn}\end{array}$ & Conesa et al. (2007b) \\
\hline
\end{tabular}




\begin{tabular}{|c|c|c|c|c|}
\hline Plant species & Family & $\begin{array}{l}\text { Remediation } \\
\text { Mechanism }\end{array}$ & Achieved Results & References \\
\hline $\begin{array}{c}\text { Festuca rubra and } \\
\text { Agrostis tenuis Sibthorp }\end{array}$ & $\begin{array}{l}\text { Both belongs to } \\
\text { Poaceae }\end{array}$ & Phytostabilization & $\begin{array}{c}\text { Successful establishment in } \\
\mathrm{Pb} / \mathrm{Zn} \text { and } \mathrm{Cu} \text { mine tailings } \\
\text { with a combination of } \\
\text { fertilizers and lime }\end{array}$ & $\begin{array}{c}\text { Smith and Bradshaw } \\
\text { (1979) }\end{array}$ \\
\hline $\begin{array}{c}\text { Alnus viridis subsp. } \\
\text { sinuate (Regel) and } \\
\text { Anaphalis margaritacea } \\
\text { (L.) }\end{array}$ & $\begin{array}{c}\text { Betulaceae, and } \\
\text { Asteraceae } \\
\text { respectively }\end{array}$ & Phytostabilization & $\begin{array}{c}\text { Demonstration of adequate } \\
\text { plant biomass and shoot } \\
\text { tissue exclusion of high } \\
\text { concentration of } \mathrm{Al} \text { and } \mathrm{Zn} \\
\text { in } \mathrm{Cu} \text { mine tailings amended } \\
\text { with biosolids-woodchip } \\
\text { mixture }\end{array}$ & Kramer et al. (2000) \\
\hline Atriplex lentiformis & Amaranthaceae & Phytostabilization & $\begin{array}{c}\text { Demonstrated adequate } \\
\text { growth in moderately acidic } \\
\text { and extremely acidic } \mathrm{Pb} / \mathrm{Zn} \\
\text { mine tailings with } 10 \% \\
\text { compost addition }\end{array}$ & Mendez et al. (2007) \\
\hline Atriplex canescens & Chenopodiaceae & Phytostabilization & $\begin{array}{c}\text { Successfully grown in } \mathrm{Cu} \\
\text { mine tailings with sludge } \\
\text { application of } 60 \mathrm{Mg} \mathrm{ha}^{-1} \\
\text { and displayed high Cu} \\
\text { concentrations in the leaves } \\
\text { tissues }\end{array}$ & Sabey et al. (1990) \\
\hline
\end{tabular}

\section{Conclusion}

Remediation of mine tailings through phytoremediation approaches is a promising strategy. Work done on phytoextraction indicated that the approach will be limited to sites where the land values are high, and the time of restoring the site will be long due to high cost and lengthy treatment times. Phytostabilization provides a more suitable generation phytoremediation approach because of its easy nature of implementation and lower cost. However, both approaches need further review and optimization to enhance complete restoration of AMD.

The Indian mustard, Brassica juncea (Brassicaceae), Chrysopogon zizanioides and an aquatic macrophyte Eichhornia crassipes have been identified to be successful in the remediation of AMD. This review suggests further research on their mechanisms of heavy metal remediations, the climatic influence, and the nutrient requirements for the development of enough biomass for phytoremediation. Furthermore, the combination of these three plant species in the remediation of most areas or mine tailings contaminated with heavy metals needs further research.

Acknowledgements. The authors wish to thank the National Research Foundation and the Agricultural Research Council - University of South Africa Climate Change Collaboration Centre for their financial support.

\section{REFERENCES}

[1] Audet, P., Charest, C. (2007): Heavy metal phytoremediation from a meta-analytical perspective. - Environmental Pollution 147: 231-237.

[2] Baker, A. J. M., Proctor, J., Reeves, R. D. (1992): The Vegetation of Ultramafic (Serpentine) Soils. - Proceedings of the First International Conference on Serpentine Ecology, University of California, Intercept, Hampshire, UK. 
[3] Baker, A. J. M., Reeves, R. D., Hajara, A. S. M. (1994): Heavy metal accumulation and tolerance in British populations of the metallophyte Thlaspi caerulescens J. \& C. Presl (Brassicaceae). - New Phytology 127: 61-68.

[4] Baker, A. J. M., McGrath, S. P., Reeves, R. D., Smith, J. A. C. (2000): Metal hyperaccumulator plants: a review of the ecology and physiology of a biological resource for phytoremediation of metal-polluted soils. - In: Terry, N., Banuelos, G. (eds.) Phytoremediation of contaminated soil and water. Lewis Publishers, Boca Raton.

[5] Baker, A. J. M., Whiting, S. M. (2002): In Search for the Holy Grail-another step in understanding metal hyperaccumulation? - New Phytologist 155: 1-7.

[6] Banerjee, R., Goswami, P., Mukherjee, A. (2018): Chapter 22 - Stabilization of Iron Ore Mine Spoil Dump Sites With Vetiver System. - In: Bio-Geotechnologies for Mine Site Rehabilitation: 393-413. Elsevier, Kolkata.

[7] Bech, J., Poschenrieder, C., Barcelo, J., Lansac, A. (2002): Plants from mine spoils in the South American area as potential sources of germplasm for phyotremediation technologies. - Acta Biotechnology 1-2: 5-11.

[8] Begonia, G. B., Davis, C. D., Begonia, M. E. T., Gray, C. N. (1998): Growth responses of Indian Mustard (Brassica juncea (L.) Czern.) and its phytoextraction of lead from a contaminated soil. - Bulletin of Environmental Contamination and Toxicology 61: 38-43.

[9] Bennett, L. E., Burkhead, J. L., Hale, K. L., Terry, N., Pilon, M., Pilon-Smits, E. A. H. (2003): Analysis of transgenic Indian mustard plants for phytoremediation of metalcontaminated mine tailings. - Journal of Environmental Quality 32: 432-440.

[10] Berti, W. W. R., Cunningham, S. D. (2000): Phytostabilization of metals. - In: Raskin, I., Ensley, B. D. (eds.) Phytoremediation of toxic metals - using plants to clean up the environment. John Wiley \& Sons, Inc., New York 71-88.

[11] Blaylock, M. J., Salt, D. E., Dushenkov, S., Zakharova, O., Gussman, C., Kapulnik, Y., Ensley, B. D., Raskin, I. (1997): Enhanced accumulation of Pb in Indian mustard by soilapplied chelating agents. - Environmental Science and Technology 31: 860-856.

[12] Blowes, D. W., Ptacek, C. J., Jambor, J. L., Weisener, C. G. (2003): The geochemistry of acid mine drainage. - In: Holland, H. D., Turekian, K. K. (eds.) Treatise on geochemistry. Oxford: Elsevier: 150-204.

[13] Brooks, R. R., Wither, E. D. (1977a): Nickel hyperaccumulation by Rinorea bengalenis (Wall.) O.K. - Journal of Geochemical Exploration 7: 295-300.

[14] Brooks, R. R., Wither, E. D. (1977b): Balt and nickel in Rinorea species. - Plant and Soil 47: 707-712.

[15] Brooks, R. R. (1998): Plants that hyperaccumulate heavy metals: their role in phytoremediation, microbiology, archaeology, mineral exploration and phytomining. $\mathrm{CAB}$ International, Wallingford.

[16] Castellanos, A. E., Martinez, M. J., Llano, J. M., Halvorson, W. L., Espiricueta, M., Espejel, I. (2005): Successional trends in Sonoran Desert abandoned agricultural fields in northern Mexico. - Journal of Arid Environment 60: 437-455.

[17] Clarke, L. (1996): Coal mining and water quality. - Journal of Mines Metals and Fuels 44: 181-183.

[18] Cobbett, C. (2003): Heavy metals and plants - model systems and hyperaccumulators. New Phytologist 159: 289-293.

[19] Conesa, H. M., Garcia, G., Faz, A., Arnaldos, R. (2007a): Dynamics of metal tolerant plant communities' development in mine tailings from the Cartagena-La Union Mining District (SE Spain) and their interest for further revegetation purposes. - Chemosphere 68: 1180-1185.

[20] Conesa, H. M., Robinson, B. H., Schullin, R., Nowack, B. (2007b): Growth of Lygeum spartum in acid mine tailings: response of plants developed from seedlings, rhizomes, and at field conditions. - Environmental Pollution 145: 700-707.

[21] Cunningham, S. D., Berti, W. R., Huang, J. W. W. (1995): Phytoremediation of contaminated soils. - Trends in Biotechnology 13: 393-397. 
[22] Cunningham, S. D., Berti, W. W. R. (2000): Phytoextraction and phytostabilization: technical, economic, and regulatory considerations of the soil-lead issue. - In: Terry, N., Banuelos, G. (eds.) Phytoremediation of contaminated soil and water. CRC Press LLC, Boca Raton.

[23] Das, P. K. (2018): Phytoremediation and Nanoremediation: Emerging Techniques for treatment of acid mine drainage water. - Defence Life Science Journal 3(2): 190-196.

[24] Del Rio-Celestino, M., Font, R., Moreno-Rojas, R., De Haro-Bailon, A. (2006): Uptake of lead and zinc by wild plants growing on contaminated soils. - Industrial Crop and Products 24: 230-237.

[25] Deng, J. C., Liao, B., Ye, M., Deng, D. M., Lan, C. Y., Shu, W. S. (2007): The effects of heavy metal pollution on genetic diversity in zinc/cadmium hyperaccumulator Sedum alfredii populations. - Plant Soil 297: 83-92.

[26] Duker, A. A., Carranza, E. J. M., Hale, M. (2005): Arsenic geochemistry and health. Environmental International 31: 631-641.

[27] Dushenkov, S. (2003): Trends in phytoremediation of radionuclides. - Plant and Soil 249: 167-175.

[28] Emenike, C. U., Jayanthi, B., Agamuthu, P., Fauziah, S. H. (2018): Biotransformation and removal of heavy metals: a review of phytoremediation and microbial remediation assessment on contaminated soil. - Environmental Reviews 26(2): 156-168.

[29] Ernst, W. H. O. (2000): Evolution of metal hyperaccumulation and the phytoremediation hype. - New Phytologist 146: 357-358.

[30] Ernst, W. H. O. (2005): Phytoextraction of mine wastes - options and impossibilities. Chemie der Erde-Geochemistry 65(1): 29-42.

[31] Evangelou, V. P. (1995): Pyrite Oxidation and its Control. - CRC Press, New York: 275.

[32] Filipek, L. H., Hatton, C., Gusek, J., Tsukamoto, T. (2003): Passive treatment of acid rock drainage (ARD): state of the practice. - In: Proceedings of the Tenth International Conference on Tailings and Mine Waste, Colorado, USA, 293-303.

[33] Fiset, J. F., Zinck, J. M., Nkinamubanzi, P. C. (2003): Chemical stabilization of metal hydroxide sludge. - In: Proceedings of the $\mathrm{X}$ International Conference on Tailings and Mine Waste, Vail, CO, USA, AA Balkema: 329-332.

[34] Forján, R., Rodríguez-Vila, A., Covelo, E. F. (2017): Increasing the nutrient content in a mine soil through the application of technosol and biochar and grown with Brassica juncea L. - Waste and Biomass Valorization: 1-17.

[35] Frérot, H., Lefébvre, C., Gruber, W., Collin, C., Santos, A., Escarré, J. (2006): Specific interactions between local metallicolous plants improve the phytostabilization of mine soils. - Plant Soil 282: 53-65.

[36] Fyson, A., Kalin, M., Adrian, L. W. (1994): Arsenic and nickel removal by wetland sediments. - In: Proceedings of the International Land Reclamation and Mine Drainage Conference and Third International Conference on the Abatement of Acidic Drainage, vol. 1. Pittsburgh, PA: 109-118.

[37] Gebauer, R. L. E., Ehleringer, J. R. (2000): Water and nitrogen uptake patterns following moisture pulses in a cold desert community. - Ecology 81: 695-712.

[38] Glick, B. R. (2003): Phytoremediation: synergistic use of plants and bacteria to clean up the environment. - Biotechnology Advances 21: 383-393.

[39] Gonzalez, R. C., Gonzalez-Chavez, M. C. A. (2006): Metal accumulation in wild plants surrounding mining wastes: soil and sediment remediation (SSR). - Environmental Pollution 144: 84-92.

[40] Hasan, S. H., Talat, M., Rai, S. (2007): Sorption of cadmium and zinc from aqueous solutions by water hyacinth (Eichchornia crassipes). - Bioresource Technolology 98(4): 918-928.

[41] Hong, M. S., Farmayan, W. F., Dortch, I. J., Chiang, C. Y., McMillan, S. K., Schnoor, J. L. (2001): Phytoremediation of MTBE from groundwater plume. - Environmental Science and Technology 35: 1231-1239. 
[42] Huang, J. W., Blaylock, M. J., Kapulnik, Y., Ensley, B. D. (1998): Phytoremediation of uranium-contaminated soils: role of organic acids in triggering uranium hyperaccumulation in plants. - Environmental Science and Technology 32: 2004-2008.

[43] Iqbal, M. C. M., Kulasekara, L., Rajakaruna, N., Iqbal, S. S. (2006): Plant-soil relations of a serpentine site in the southern coast of Sri Lanka. - Fifth International Conference on Serpentine Ecology. Siena, Italy, 09-13 May. (Abstract).

[44] Jaffré, T., Brooks, R. R., Lee, J., Reeves, R. D. (1976): Seberita acuminata: a hyperaccumlator of nickel from New Caledonia. - Science 193: 579-580.

[45] Jaffré, T., Kersten, W., Brooks, R. R., Reeves, R. D. (1979): Nickel uptake by Flacourtiaceae of New Caledonia. - Proceedings of the Royal Society of London B205: 385-394.

[46] Jayasekera, R., Rossbach, M. (1994): Trace elements in plants growing in contrasting ecosystems in Sri Lanka: analytical aspects. - Environmental Geochemistry and Health 16: 171-179.

[47] Jayasekera, R., Rossbach, M. (1996): Background levels of heavy metals in plants of different taxonomic groups from a montane rain forest in Sri Lanka. - Environmental Geochemistry and Health 18: 55-62.

[48] Jefferson, L. V. (2004): Implications of plant density on the resulting community structure of mine site land. - Restoration Ecology 12: 429-438.

[49] Jopony, M., Tongkul, F. (1999): Hyperaccumulation of nickel by Rinorea benghalensis in ultrabasic soils of Sabah, Malaysia. - Third International Conference on Environmental Chemistry and Geochemistry in the Tropics. Hong Kong, 24-26 November. (Abstract).

[50] Keller, C., Hammer, D., Kayser, A., Richner, W., Brodbeck, M., Sennhauser, M. (2003): Root development and heavy metal phytoextraction efficiency: comparison of different plant species in the field. - Plant Soil 249: 67-81.

[51] Kleinman, R. L. P. (1990): Acid mine drainage, US bureau of mines researches and develops: control methods for both coal and metal mines. - Environmental Science and Technology 24(9): 1278-1285.

[52] Knight, B., Zhao, F. J., McGrath, S. P., Shen, Z. G. (1997): Zinc and cadmium uptake by the hyperaccumulator Thlaspi caerulescens in contaminated soils and its effects on the concentration and chemical speciation of metals in soil solution. - Plant Soil 197: 71-78.

[53] Kramer, P. A., Zabowski, D., Scherer, G., Everett, R. L. (2000): Native plant restoration of copper mine tailings: I. Substrate effect on growth and nutritional status in a greenhouse study. - Journal of Environmental Quality 29: 1762-1769.

[54] Krämer, U. (2003): Phytoremediation to phytochelatin - plant trace metal homeostasis. New Phytologist 158: 4-6.

[55] Krzaklewski, W., Pietrzykowski, M. (2002): Selected physicochemical properties of zinc and lead ore tailings and their biological stabilisation. - Water Air Soil Pollution 141: $125-142$.

[56] Kumar, P. B. A. N., Dushenkov, V., Motto, H., Raskin, I. (1995): Phytoextraction: the use of plants to remove heavy metals form soils. - Environmental Science and Technology 29: 1232-1238.

[57] Kuyucak, N. (2002): Acid mine drainage prevention and control options. - CIM Bulletin 95(1060): 96-102.

[58] Lasat, M. M., Fuhrmann, M., Ebbs, S. D., Cornish, J. E., Kochian, L. V. (1998): Phytoremediation of a radiocesium-contaminated soil: evaluation of cesium-137 bioaccumulation in the shoots of three plant species. - Journal of Environmental Quality 27: 165-169.

[59] Leita, L., De Nobili, M., Pardini, G., Ferrari, F., Sequi, S. (1989): Anomalous contents of heavy metals in soils and vegetation of a mine area in S.W. Sardinia, Italy. - Water Air Soil Pollution 48: 423-433. 
[60] Lutts, S., Lefevre, I., Delperee, C., Kivits, S., Dechamps, C., Robledo, A., Correal, E. (2004): Heavy metal accumulation by the halophyte species Mediterranean saltbush. Journal of Environmental Quality 33: 1271-1279.

[61] Mannino, I., Franco, D., Piccioni, E., Favero, L., Mattiuzzo, E., Zanetto, G. (2008): A cost-effectiveness analysis of seminatural wetlands and activated sludge wastewatertreatment systems. - Environmental Management 41: 118-129.

[62] Marschner, H. (1995): Mineral nutrition of higher plants. - Academic Press Inc., San Diego.

[63] McGaw, L. J., Rabe, T., Sparg, S. G., Jäger, A. K., Eloff, J. N., van Staden, J. (2001): An investigation on the biological activity of Combretum species. - Journal of Ethnopharmacology 75(1): 45-50.

[64] Meerts, P., Van Isacker, N. (1997): Heavy metal tolerance and accumulation in metallicolous and non-metallicolous populations of Thlaspi caerulescens from continental Europe. - Plant Ecology 133: 221-231.

[65] Melato, F. A., Mokgalaka, N. S., McCrindle, R. I. (2016): Adaptation and detoxification mechanisms of Vetiver grass (Chrysopogon zizanioides) growing on gold mine tailings. International Journal of Phytoremediation 18(5): 509-520.

[66] Mendez, M. O., Glenn, E. P., Maier, R. M. (2007): Phytostabilization potential of quailbush for mine tailings: growth, metal accumulation, and microbial community changes. - Journal of Environmental Quality 36: 245-253.

[67] Michelle, B.da-C., Rosane, A., Jaime, W. V.de-M. (2010): Phytoremediation of acid mine drainage by aquatic floating macrophytes. - Institute of Science and Technology for Mineral Resource, Water and Biodiversity, INCT-ACQUA - Annual Report 1-4.

[68] Mishra, V. K., Upadhyaya, A. R., Pandey, S. K., Tripathi, B. D. (2008a): Heavy metal pollution induced due to coal mining effluent on surrounding aquatic ecosystem and its management through naturally occurring aquatic macrophytes. - Bioresourse Technology 99: 930-936.

[69] Mishra, V. K., Upadhyaya, A. R., Pandey, S. K., Tripathi, B. D. (2008b): Phytoremediation of mercury and Arsenic from Tropical open cast coalmine effluent through naturally occurring aquatic macnophtes. - Water, Air and Soil Pollution 192: 303-314.

[70] Modis, K., Adam, K., Panagopoulos, K., Komtopoulos, A. (1998): Development and Validation of a geostatistical model for prediction of acid mine drainage in underground sulphide mines. - Journal of Transaction of the Institute of Mining and Metallurgy (Sect A: Min. Industry) A102-A107.

[71] Mokhtar, H., Morad, N., Ahmad Fizri, F. F. (2011): Hyperaccumulation of copper by two species of aquatic plants. - International Conference on Environmental Science and Engineering IPCBEE 8. IACSIT Press, Singapore.

[72] Mummey, D. L., Stahl, P. D., Buyer, J. S. (2002a): Microbial biomarkers as an indicator of ecosystem recovery following surface mine reclamation. - Applied Soil Ecology 21: 251-259.

[73] Mummey, D. L., Stahl, P. D., Buyer, J. S. (2002b): Soil microbiological properties 20 years after surface mine reclamation: spatial analysis of reclaimed and undisturbed sites. - Soil Biology and Biochemistry 34: 1717-1725.

[74] Munshower, F. F. (1994): Practical handbook of disturbed land revegetation. - Lewis Publishing, Boca Ratton.

[75] National Research Council. (2005): Mineral tolerance of animals. - National Academies Press, Washington.

[76] Newete, S. W., Byrne, M. J. (2016): The capacity of aquatic macrophytes for phytoremediation and their disposal with specific reference to water hyacinth. Environmental Science and Pollution Research 23(11): 10630-10643.

[77] Osmond, C. B., Bjorkman, O., Anderson, D. J. (1980): Physiological processes in plant ecology: toward a synthesis with Atriplex. - Springer-Verlag, New York. 
[78] Pichtel, J., Salt, C. A. (1998): Vegetative growth and trace metal accumulation on metalliferous wastes. - Journal of Environmental Quality 27: 618-624.

[79] Pierzynski, G. M., Lambert, M., Hetricck, B. A. D., Weeney, D. W., Erickson, L. E. (2002): Phytostabilization of metal mine tailings using tall fescue. - Practical Periodical Hazard and Toxic Radioactive Waste Manage 6: 212-217.

[80] Piha, M. I., Vallack, H. W., Michael, N., Reeler, B. M. (1995): A lowinput approach to vegetation establishment on mine and coal ash wastes in semiarid regions. 2. Lagooned pulverized fuel ash in Zimbabwe. - Journal of Applied Ecology 32: 382-390.

[81] Pilon-Smits, E., Pilon, M. (2002): Phytoremediation of metals using transgenic plants. Critical Review in Plant Science 21: 439.

[82] Pilon-Smits, E. A. H. (2005): Phytoremediation. - Annual Review of Plant Biology 56: 15-39.

[83] Prasad, M. N. V., Freitas, H. M. O. (2003): Metal hyperaccumulation in plantsBiodiversity prospecting for phytoremediation technology. - Electronic Journal of Biotechnology 6: 285-321.

[84] Proctor, J. (2003): Vegetation and soil and plant chemistry on ultramafic rocks in the tropical Far East. - Perspectives in Plant Ecology, Evolution, and Systematics 6: 105-124.

[85] Proctor, J., Phillipps, C., Duff, G. K., Heaney, A., Robertson, F. M. (1989): Ecological studies in Gunung Silam, a small ultrabasic mountain in Sabah, Malaysia. II. Some forest processes. - Journal of Ecology 77: 317-331.

[86] Qadir, S., Qureshi, M. I., Javed, S., Abdin, M. Z. (2004): Genotypic variation in phytoremediation potential of Brassica juncea cultivars exposed to Cd stress. - Plant Science 167: 1171-1181.

[87] Rahman, M. A., Hasegawa, H., Ueda, K., Maki, T., Okumura, C., Rahman, M. M. (2007): Arsenic accumulation in duckweed (Spirodela polyrhiza L.): a good option for phytoremediation. - Chemosphere 69(3): 493-499.

[88] Rai, P. K. (2008): Heavy metal pollution in aquatic ecosystems and its phytoremediation using wetland plants: an Eco-sustainable approach. - International Journal of Phytoremediation 10(2): 131-158.

[89] Rajakaruna, N., Bohm, B. A. (2002): Serpentine and its vegetation: a preliminary study from Sri Lanka. - Journal of Applied Botany 76: 20-28.

[90] Rajakaruna, N., Baker, A. J. M. (2004): Serpentine: A model habitat for botanical research in Sri Lanka. - Ceylon Journal of Science (Biological Sciences) 32: 1-19.

[91] Ramadan, T. (2001): Dynamics of Salt Secretion by Sporobolus spicatus (Vahl) Kunth from Sites of Differing Salinity. - Annals of Botany 87: 259-266.

[92] Reeves, R. D. (2003): Tropical hyperaccumulators of metals and their potential for phytoextraction. - Plant and Soil 249: 57-65.

[93] Rosario, K., Iverson, S. L., Henderson, D. A., Chartrand, S., McKeon, C., Glenn, E. P., Maier, R. M. (2007): Bacterial community changes during plant establishment at the San Pedro River mine tailings site. - Journal of Environmental Quality 36: 1249-1259.

[94] Sabey, B. R., Pendleton, R. L., Webb, B. L. (1990): Effect of municipal sewage-sludge application on growth of two reclamation shrub species in copper mine spoils. - Journal of Environmental Quality 19: 580-586.

[95] Salt, D. E., Pickering, I. J., Prince, R. C., Gleba, D., Dushenkov, S., Smith, R. D., Raskin, I. (1997): Metal accumulation by aquacultured seedlings of Indian mustard. Environmental Science and Technology 31: 1636-1644.

[96] Schmidt, U. (2003): Enhancing phytoextraction: the effect of chemical soil manipulation on mobility, plant accumulation, and leaching of heavy metals. - Journal of Environmental Quality 32: 1939-1954.

[97] Sharma, S., Singh, B., Manchanda, V. K. (2014): Phytoremediation: role of terrestrial plants and aquatic macrophytes in the remediation of radionuclides and heavy metal contaminated soil and water. - Environmental Science and Pollution Research 22(2): 946-962. 
[98] Shu, W. S., Ye, Z. H., Lan, C. Y., Zhang, Z. Q., Wong, M. H. (2001): Acidification of lead/zinc mine tailings and its effect on heavy metal mobility. - Environmental International 26: 389-394.

[99] Singh, G., Bhati, M., Rathod, T. (2010): Use of tree seedlings for the phytoremediation of a municipal effluent used in dry areas of north-western India: Plant growth and nutrient uptake. - Ecological Engineering 36(10): 1299-1306.

[100] Smith, R. A. H., Bradshaw, A. D. (1979): The use of metal tolerant plant populations for the reclamation of metalliferous wastes. - Journal of Applied Ecology 16: 595-612.

[101] Snow, A. A., Andow, D. A., Gepts, P., Hallerman, E. M., Power, A., Tiedje, J. M., Wolfenbarger, L. L. (2005): Genetically engineered organisms and the environment: current status and recommendations. - Ecological Application 10: 377-404.

[102] Sood, A., Uniyal, P. L., Prasanna, R., Ahluwalia, A. S. (2012): Phytoremediation potential of aquatic macrophyte, Azolla. - Ambio 41: 122-137.

[103] Stoffberg, G. H., van Rooyen, M. W., van der Linde, M. J., Groeneveld, H. T. (2008): Predicting the growth in tree height and crown size of three street tree species in the City of Tshwane, South Africa. - Urban Forestry and Urban Greening 7: 259-264.

[104] Tilman, D. (1988): Plant strategies and the dynamics and structure of plant communities. - Princeton University Press, New Jersey.

[105] Tucker, R. K., Shaw, J. A. (2000): Phytoremediation and public acceptance. - In: Raskin, I., Ensley, B. D. (eds.) Phytoremediation of toxic metals. Using plants to clean up the environment. J. Wiley \& Sons, New York, USA: 33-42.

[106] Turnau, K., Henriques, F. S., Anielska, T., Renker, C., Buscot, F. (2007): Metal uptake and detoxification mechanisms in Erica andevalensis growing in a pyrite mine tailing. Environmental and Experimental Botany 61: 117-123.

[107] Van Rensburg, L., Morgenthal, T. (2004): The effect of woodchip waste on vegetation establishment during platinum tailings rehabilitation. - South African Journal of Science 100: 294-300.

[108] Von Willert, F. J., Stehouwer, R. C. (2003): Compost and calcium surface treatment effects on subsoil chemistry in acidic minespoil columns. - Journal of Environmental Quality 32: 781-788.

[109] Watson, I. W., Westoby, M., Holm, A. M. (1997): Continuous and episodic components of demographic change in arid zone shrubs: models of two Eremophila species from Western Australia compared with published data on other species. - Journal of Ecology 85: 833-846.

[110] Windsor, D. M., Clements, A. (2001): A germination and establishment field trial of Themeda australis (kangaroo grass) for mine site restoration in the Central Tablelands of New South Wales. - Restoration Ecology 9: 104-110.

[111] Wither, E. D., Brooks, R. R. (1977): Hyperacumulation of nickel by some plants of Southeast Asia. - Journal of Geochemical Exploration 8: 579-583.

[112] Wolfe, A. K., Bjornstad, D. J. (2002): Why would anyone object? An exploration of social aspects of phytoremediation acceptability. - Critical Review in Plant Science 21: 429-438.

[113] Wolfenbarger, L. L., Phifer, P. R. (2000): Biotechnology and ecology-the ecological risks and benefits of genetically engineered plants. - Science 290: 2088-2093.

[114] Wong, M. H. (2003): Ecological restoration of mine degraded soils, with emphasis on metal contaminated soils. - Chemosphere 50: 775-780.

[115] Wood, M. K., Buchanan, B. A., Skeet, W. (1995): Shrub preference and utilization by big game on New Mexico reclaimed mine land. - Journal of Range Management 48: 431437.

[116] Wu, J., Hsu, F. C., Cunningham, S. D. (1999): Chelate-assisted Pb phytoextraction: Pb availability, uptake, and translocation constraints. - Environmental Science and Technology 33: 1898-1904. 
[117] Ye, Z. H., Wong, J. W. C., Wong, M. H., Lan, C. Y., Baker, A. J. M. (1999): Lime and pig manure as ameliorants for revegetating lead/ zinc mine tailings: a greenhouse study. Bioresource Technology 69: 35-43.

[118] Zhao, F. J., Lombi, E., McGrath, S. P. (2003): Assessing the potential for zinc and cadmium phytoremediation with the hyperaccumulator Thlaspi caerulescens. - Plant Soil 249: 37-43.

[119] Zhu, Y. L., Pilon-Smits, E. A. H., Jouanin, L., Terry, N. (1999): Overexpression of gluthathione synthetase in Brassica juncea enhances cadmium tolerance and accumulation. - Plant Physiology 119: 73-79. 